\title{
HUBUNGAN FUNGSI DAN TATA KERJA \\ DEWAN PERWAKILAN RAKYAT DAERAH DENGAN BUPATI \\ MENURUT UNDANG UNDANG NOMOR 32 TAHUN 2004 \\ (Studi di Kabupaten Sumbawa Barat)
}

\author{
Linayati Lestari \\ Dosen Tetap Program Studi Ilmu Pemerintahan \\ Fakultas Ilmu Sosial dan Ilmu Politik Universitas Riau Kepulauan \\ linayatilestari@yahoo.com
}

\section{ABSTRACT}

The purpose of this study was to determine the grounding normative functional in relation to the workings of Parliament with the Regent, the mechanism of relations functions and Working Procedure of the Regional Representatives Council with the Regional Head in the local government system in accordance with Law No. 32 of 2004, as well as menetahui factors affect the functioning and working procedures of Parliament with the Regional Head of governance in the region of West Sumbawa regency. Problems of law functions in relation to the working procedures of the Regional Representatives Council (hereinafter abbreviated $D P R D)$ with Regent interesting to study. It concerns the functional normative grounding in the workings of Parliament relations with the Regent, the mechanism of structural-function relationships work procedures, as well as the factors that influence it. Basically the function of the relationship between the workings of Parliament with the Regents set forth in Article 41 of Law Number 32 Year 2004 on Regional Government, which states: Parliament has a legislative function, budgeting, and oversight. This relationship continues to change.

The approach taken in this study is the first is a normative approach, it is oriented as the workings of Parliament relations with the Regent based on the rule of law. With regard to the approach taken, are: (statute approach) the approach through the fundamental role assumed by local institutions is carried out according to the function and the main task; in addition, used the conceptual approach which is done in this approach explains the concept in accordance with the current state (conseptual approach). Then the second is: the law of the empirical approach (Socio-legal approach) that is the approach that examines the law in reality.

Results of this study that the association functions and working procedures of the Parliament with the Regional Head both in Law No. 22 of 1999 and Law of the Republic of Indonesia Number 32 Year 2004 on Regional Government is the same that includes relations legislation, elections, budgets, accountability, oversight, administration, initiatives and aspirations of the people. But the Law of the Republic of Indonesia Number 32 of 2004 on regional governance, providing opportunities in the implementation of the regional administration in the "good governance" in the Republic of Indonesia Year 1945 and Pancasila. Relations functions and working procedures of Parliament with the implementation is very influenced by juridical and non factor juridical, where the laws of 
local government is now explicitly regulate the relationship organ system of the new government to further clarify and reinforce the hierarchical relationship between the district / city to the provinces.

\section{Keywords : relationship, functions and working procedures, legislative}

\section{A. PENDAHULUAN}

Permasalahan fungsi hukum dalam hubungan tata kerja Dewan Perwakilan Rakyat Daerah (selanjutnya disingkat DPRD) dengan Bupati menarik untuk diteliti. Hal itu berkenaan dengan landasan normatif fungsional dalam hubungan tata-kerja DPRD dengan Bupati, mekanisme secara struktural fungsi hubungan tata-kerja tersebut, serta faktor yang mempengaruhinya.

Pada dasarnya fungsi hubungan tata-kerja antara DPRD dengan Bupati diatur dalam Pasal 41 Undang-undang Nomor 32 Tahun 2004 tentang Pemerintahan Daerah, yang menyatakan: DPRD memiliki fungsi legislasi, anggaran, dan pengawasan. Hubungan ini terus mengalami perubahan. Munculnya gerakan reformasi yang disertai gelombang tuntutan ketidakpuasan masyarakat di berbagai daerah mengenai pola hubungan antara pusat dan daerah yang dirasakan tidak adil, sehingga mendorong pemerintah untuk mempercepat pelaksanaan kebijakan otonomi. Desakan ini akhirnya menghasilkan penggantian Undang-undang Nomor 5 Tahun 1974 dengan Undang-undang Nomor 22 Tahun 1999 tanpa di barengi perubahan Undang-Undang Dasar 1945, dan sekitar tiga setengah tahun pemberlakuannya undang-undang Nomor 22 diganti lagi dengan Undang-undang Nomor 32 Tahun 2004 tentang Pemerintahan daerah.

Kedudukan hukum DPRD pada era reformasi dewasa ini mengalami proses reposisi yang cukup radikal. Pada masa lampau, kedudukan DPRD adalah salah satu unsur dari pemerintahan daerah atau eksekutif (pasal 11 UU Nomor 5 tahun 1974). Ini berarti bahwa DPRD memang diposisikan sebagai mitra Kepala Daerah dalam perumusan sekaligus implementasi kebijakan di daerah, dari pada sebagai fungsi kontrol dan penyeimbang kekuatan eksekutif yang sangat besar. Dalam kedudukannya yang demikian, sangatlah wajar jika DPRD sama sekali tidak mencerminkan representasi dari rakyat di daerahnya. Oleh karena itulah dalam pasal 14 Undang-undang Nomor 22 tahun 1999 kedudukan DPRD dikembalikan kepada fungsi aslinya, yakni sebagai badan legislatif.

Seiring dengan fungsi barunya ini, DPRD juga diberikan hak untuk meminta pertanggungjawaban Kepala Daerah, sesuatu yang sangat tidak mungkin terjadi dalam era Orde Baru. Dalam konteks negara demokrasi dan negara hukum, kedudukan DPRD 
mutlak harus memiliki kemandirian dan "kekebalan" dari pengaruh-pengaruh kekuasaan lainnya, baik dari pihak eksekutif maupun pengaruh-pengaruh yang datang dari kelompok-kelompok penekan (pressure group). Jika DPRD tidak mampu melepaskan diri dari pengaruh-pengaruh ini, maka yang terjadi adalah "pengkhianatan" terhadap amanat rakyat. Dan jika hal ini terjadi, maka dapat dikatakan bahwa fungsi DPRD tidak lebih hanya sebagai perpanjangan tangan dari berbagai pihak yang "menguasainya" tadi. Itulah sebabnya, untuk menjaga dan mengantisipasi intervensi dan pengaruh kekuasaan lain terhadap DPRD, lembaga legislatif idealnya hanya memiliki hubungan kerja dan koordinasi dengan lembaga-lembaga di luar dirinya, namun secara struktural tidak memiliki hubungan langsung secara kedinasan (line and staff). Meskipun demikian, tidak berarti bahwa lembaga legislatif harus selalu dominan terhadap lembaga eksekutif. Kecuali dalam sistem ketatanegaraan parlementer, kedudukan eksekutif (yang dipersonifikasikan oleh Kepala Daerah) dan legislatif haruslah seimbang.

Bahkan konsep Trias Politika yang diintroduksi oleh Montesquieu secara tegas memisahkan hubungan antara kedua lembaga ini; dengan kata lain tidak dapat saling mencampuri (dan oleh karenanya tidak dapat saling menjatuhkan). Namun sayangnya, realitas politik di Indonesia pasca pemberlakuan Undang-undang Nomor 22 tahun 1999 menunjukkan adanya pembalikan posisi, di mana DPRD yang semula hanya merupakan "bagian/unsur dari pemerintah daerah" menjadi lembaga yang berhak meminta pertanggungjawaban Kepada Daerah. Dengan kata lain, kedudukan DPRD berubah dari inferior menjadi superior terhadap Kepala Daerah.

Fungsi pembuatan hukum, secara umum dipahami bahwa kekuasaan legislatif merupakan fungsi kenegaraan dalam bidang perumusan atau pembuatan hukum. Bahkan ajaran pembagian kekuasaan (division of power) menurut Trias Politika menandaskan bahwa hanya DPR saja yang mewakili rakyat dan memiliki kompetensi untuk mengungkapkan kehendak rakyat dalam bentuk Undang-Undang, sementara eksekutif atau pemerintah hanya mengikuti dan mengimplementasikan hukum (UU) yang ditetapkan oleh DPR.

Inilah pandangan "supremasi parlementarisme" yang cenderung semakin memudar. Sistem pemerintahan di Indonesia sendiri mendistribusikan kekuasaan legislatif kepada dua lembaga tinggi negara yakni Presiden dan DPR. Meskipun pasal 5 UUD 1945 telah diamendemen, namun dalam prakteknya fungsi pembuatan undangundang masih memerlukan keterlibatan eksekutif dan legislatif secara bersama-sama. Harus diakui bahwa DPR (walaupun dalam era reformasi) belum mampu secara penuh 
dibebani tugas perumusan undang-undang. Oleh karena itu, inisiatif dan kajian tentang isi (content analysis) suatu rencana undang-undang sebagian besar berasal dari kalangan birokrasi.

Akar masalah dari rendahnya produktivitas anggota legislatif disebabkan antara lain karena tingkat pendidikan anggota legislatif relatif lebih rendah disamping kurangnya atau terbatasnya informasi dan data yang dimilikinya. Sekali lagi hal ini mengindikasikan bahwa posisi anggota legislatif perlu lebih diberdayakan. Pemahaman yang benar dan mendalam tentang lingkungan strategis yang melingkupi organisasinya perlu dibangun seiring dengan berbagai upaya untuk memperluas wawasan dan kapasitas individu anggota legislatif. Hal ini perlu ditempuh agar DPR/DPRD benar-benar muncul sebagai lembaga yang independen, profesional dan mampu berkomunikasi dengan rakyat secara transparan, jujur dan efektif.

Mengingat kinerja politik yang masih sangat rendah, maka sangatlah wajar jika kedudukan DPR/DPRD merupakan mitra atau partner bagi Presiden/Kepala Daerah dalam penyusunan kebijaksanaan. Atau dengan kata lain, antara eksekutif dan legislatif tidak hanya sama-sama memiliki hak untuk mengajukan rancangan undang-undang, namun lebih dari itu juga sama-sama memiliki tanggungjawab untuk memajukan daerahnya. "Perseteruan" baik terbuka maupun diam-diam antara DPRD dan Kepala Daerah, atau sebaliknya kolusi antara keduanya dengan prinsip mutual understanding, jelas-jelas merupakan "pelacuran politik", "penyimpangan kekuasaan", sekaligus "korupsi administratif" dari para aktor atau politisi lokal.

Untuk mengantisipasi berlarutnya mis-interpretasi dari proses pemberdayaan institusi lokal, maka kedudukan DPRD perlu ditempatkan pada posisi yang benar-benar proporsional. Meskipun Undang-undang Nomor 22 tahun 1999, dalam Pasal 19 mengatur bahwa "DPRD berhak meminta pertanggungjawaban Gubernur, Bupati, dan Walikota"; juga dala Pasal 31 "Dalam menjalankan tugas dan kewenangan sebagai Kepala Daerah, Gubernur bertanggung jawab kepada DPRD Propinsi"; serta "Dalam menjalankan tugas dan kewenangan selaku Kepala Daerah, Bupati/Walikota bertanggung jawab kepada DPRD Kabupaten/Kota", namun terdapat Pasal lainnya, yakni Pasal 16 yang menegaskan bahwa DPRD sebagai Badan Legislatif Daerah berkedudukan sejajar dan menjadi mitra dari Pemerintah Daerah. Disamping itu, tidak ada ketentuan secara eksplisit bahwa DPRD dapat memecat atau memberhentikan Kepala Daerah. Dalam hal ini, Pasal 46 menyatakan: "Bagi Kepala Daerah yang pertanggungjawabannya ditolak untuk kedua kalinya, DPRD dapat mengusulkan pemberhentiannya kepada Presiden". Implikasinya 
jelas bahwa pertanggungjawaban Kepala Daerah kepada DPRD hanya sebatas dalam fungsi kontrol terhadap pelaksanaan peraturan daerah serta jalannya pemerintahan secara umum di daerah, bukan fungsi pertanggungjawaban itu sendiri.

Masyarakat sebagai Pelanggan, Dalam konteks mencari format baru hubungan eksekutif-legislatif di daerah. Tulisan ini ingin menekankan sekali lagi bahwa kedua institusi publik tersebut bukanlah institusi yang harus saling berhadapan. Justru keduanya perlu menempatkan diri pada wadah yang sama guna menghadapi "lawan" di hadapannnya, yaitu kemelaratan masyarakat. Disebut "lawan", karena sesungguhnya hanya masyarakatlah yang berwenang untuk "mengadili" kedua institusi tadi, berhak memutuskan bahwa pemerintah daerah tidak akuntabel, serta berhak menurunkan pejabat pemerintahan daerah (baik Ketua DPRD, Kepala Daerah maupun jajarannya). Untuk dapat menghadapi "lawan" dengan baik, sudah saatnya pemerintah daerah merubah paradigmanya, yakni menempatkan masyarakat sebagai pelanggan. Inti dari gagasan ini adalah bahwa terhadap suatu keberhasilan perlu diberikan penghargaan dan atas setiap kegagalan perlu dikenakan sanksi tertentu, sehingga model ini disebut juga sebagai competitive local government. Dalam kedudukan masyarakat sebagai pelanggan, adalah sangat penting bagi pemerintah untuk memperbarui "kontrak sosial" yang baru di bidang pelayanan umum.

Untuk kasus Indonesia, tanggung jawab pemberian layanan umum berada pada pundak pemerintah daerah. Tentu saja jika ingin meniru model Inggris, perjanjian dapat dilakukan bukan antara Pemerintah Pusat dengan Dewan Kota (Pemerintah Daerah dan DPRD), namun antara Pemerintah Daerah dengan perwakilan masyarakat (DPRD ditambah dengan unsur NGO). Dengan model terobosan seperti ini, diharapkan tercapai dua manfaat sekaligus yaitu mengurangi tingkat perseteruan antara DPRD dengan Kepala Daerah dan meningkatkan kinerja pelayanan umum.

\section{B. PEMBAHASAN DAN ANALISIS}

\section{Hubungan Tatakerja DPRD dengan Bupati menurut UU no. 32 Tahun 2004 studi di Sumbawa Barat}

Lengsernya Presiden Soeharto pada 21 Mei 1998 kemudian disusul dengan pemberlakuan kebijakan desentralisasi dan liberalisasi politik pada 1999 berakibat pada pergeseran locus politik yang pada dasarnya bergerak dalam dua arah secara serentak. Pergeseran pertama membawa kekuasaan yang semula bertitik berat di eksekutif kini bertitik berat legislatif. Pergeseran kedua menarik kekuasaan yang semula tersentralisir di 
pusat kemudian dilimpakan ke daerah. Kedua pergeseran ini mengarah pada satu titik tunggal, yaitu legislatif di daerah. Akan tetapi penguatan legislatif ini ternyata tidak dibarengi oleh set up agenda yang disepakati bersama dengan eksekutif. Akibatnya, penguatan tersebut belum banyak membawa implikasi positif bagi demokratisasi, dan bahkan membawa persoalan dalam hubungan eksekutif-legislatif di daerah seperti dalam Kasus Sampang, Madura, terkait dengan terpilihnya kembali Fadhilan Budiono untuk masa jabatan kali kedua.

Menurut Gaffar Karim, sumber ketegangan politik antara eksekutif dan legislatif di daerah seperti di Sampang, bukan saja karena perbedaan alamiah mereka, melainkan karena warisan sistem pemerintahan orde baru. Berakhirnya pemerintahan yang sentralistik ternyata berimplikasi ke pemerintahan daerah, hal ini ditandai dengan adanya pergeseran locus politik sebagai akibat dari diterapkannya UU No. 22/1999 dan UU No. 4/1999 tentang Pemilu. Pada akhirnya terjadi perpindahan pola kekuasaan dari pemerintahan oleh birokrasi (bureucratic government) pada pemerintahan partai (party government).

Pada masa orde baru ada usaha yang dilakukan secara sistematik untuk menjadikan DPRD menjadi tidak berfungsi sebagai lembaga legislatif, sehingga lembaga legislatif dikenal hanya sebagai lembaga' tukang stempel' saja. Namun hal ini kemudian berbeda ketika UU pengganti UU N. 5/1974 diberlakukan yaitu UU No. 22/1999. Dibawah UU No. 22/1999 DPRD diberi kewenangan dan hak yang luar biasa luasnya, bahkan cenderung bombastis dan diluar perhitungan (Marbun, 2006: 148). Kalau kita amati dengan teliti maka akan terlihat bahwa UU No. 22/1999 telah melahirkan terobosan baru terhadap kedudukan dan peranan DPRD, yang selama 32 tahun Orde Baru terkesan mandul dan tidak berdaya dan lebih banyak berperan sebagai " hiasan politik" . Beberapa terobosan tersebut dapat diidentifikasi sebagai berikut:

a. DPRD tidak lagi ditempatkan sebagai bagian dari Pemerintah Daerah, tetapi sebagai Badan Legislatif Daerah (pasal 13);

b. Pilkada tidak lagi menjadi kewenangan Pemerintah Pusat, tetapi menjadi kewenangan DPRD;

c. Kepala Daerah memimpin penyelenggaraan Pemerintahan Daerah berdasarkan kebijakan yang ditetapkan bersama DPRD;

d. Kepala Daerah dalam menjalankan tugas dan kewajibannya bertanggungjawab kepada DPRD, dan wajib menyampaikan pertanggungjawaban kepada DPRD 
pada setiap akhir tahun anggaran. Kepala Daerah juga wajib memberikan pertanggungjawaban kepada DPRD untuk hal tertentu atas permintaan DPRD;

e. DPRD dapat mengusulkan pemberhentian Kepala Daerah kepada Presiden apabila pertangungjawabannya ditolak untuk kedua kalinya oleh DPRD;

f. DPRD dapat memaksa seorang pejabat negara, atau pejabat pemerintah, atau bahkan warga negara kebanyakan untuk memberikan keterangan di hadapan DPRD, kalau memang lembaga tersebut merasa memerlukan keterangan atau informasi dari pejabat ataupun warga masyarakat.

Berhubung UU No. 22/1999 dalam praktiknya dianggap banyak menyebabkan jalannya pemerintahan daerah tidak stabil karena munculnya dinamika politik dan kebijakan yang tidak harmonis baik antara kepala daerah dan DPRD; daerah-pusat; maupun daerah dan kepentingan dunia usaha, dan ditambah dengan adanya perubahan konstitusi yang berimplikasi terhadap peraturan perudang-undangan di bawahnya, maka kemudian tersebut diganti dengan UU yang baru yaitu No. 32/2004.

Sesuai dengan kondisi politik pasca amandemen UUD 1945, maka rumusan tentang kedudukan DPRD dalam UU No. 32/2004 mengalami perubahan mendasar, dan hampir mirip seperti kembali kepada keadaan dan suasana UU No. 5/1974. Hal itu terlihat dalam rumusan tentang Pemerintahan Daerah. Dalam rumusan pasal 3 ayat (1) UU No. 32/2004 disebutkan:

Pemerintah daerah adalah:

a. Pemerintahan daerah propinsi yang terdiri atas pemerintah daerah provinsi dan DPRD propinsi;

b. Pemerintahan daerah kabupaten/kota terdiri dari pemerintah daerah kabupaten/kota dan DPRD kabupaten kota.

Lebih jauh dirumuskan bahwa DPRD merupakan lembaga perwakilan rakyat daerah dan berkedudukan sebagai unsur penyelenggaraan pemerintahan daerah (pasal 40 UU No. 32/2004). Hal ini sepintas dapat diangap sebagai kemunduran kalau dikaitkan dengan rumusan pasal dalam UU No. 22/1999 (pasal 14 dan 16) yang menyatakan bahwa DPRD sebagai Badan Legislatif Daerah dan Pemerintah Daerah sebagai Badan Eksekutif Daerah. DPRD sebagai Badan Legislatfi Daerah berkedudukan sejajar dan menjadi mitra dari Pemerintah Daerah.

Selain itu, terkait dengan hubungannya dengan Kepala Daerah, ada dua tugas DPRD yang sebelumnya dimiliki berdasarkan UU No. 22/1999 tidak lagi dicantumkan 
dalam UU No. 32/2004 yaitu dalam hal pencalonan dan pemilihan kepala daerah dan pertanggungjawab kepala daerah kepada DPRD. Hal ini menyebabkan berkurangnya ketergantungan posisi kepala daerah kepada DPRD.

\section{Mekanisme Hubungan Kerja DPRD dan Bupati di Sumbawa Barat.}

Dalam sistem politik saat ini yang jauh lebih demokratis dibanding era orde baru, problem hubungan kepala daerah-DPRD tidak lagi terletak pada prinsip-prinsip berpemerintahan demokratis. Prinsip-prinsip dimaksud seperti prinsip checks and balances; prinsip negara hukum; prinsip kedaulatan rakyat; prinsip otonomi; dan lain-lain sudah diterima dengan mantap. Bahkan, prinsip kesejajaran dan kemitraan antara kepala daerah dan DPRD pun diterima sebagai acuan dalam rumusan hubungan kepala daerahDPRD.

Problem mendasar dari setiap masalah yang timbul dalam hubungan kepala daerah-DPRD sebenarnya adalah terletak pada kegagalan operasionalisasi konsep dan praktik dari prinsip-prinsip tersebut di atas. Sebagai contoh, ketidakberdayaan DPRD di hadapan kepala daerah pada masa orde baru itu berakar pada operasionalisasi prinsip checks and balances yang tidak tepat dalam rumusan konsep pemerintah daerah terdiri dari kepala daerah dan DPRD dalam UU No. 5/1974. Akibatnya, DPRD tidak dapat menjadi pengawas dan pengimbang kekuasaan pemerintah daerah yang efektif karena ia menjadi bagian dari pemerintah daerah.

Contoh lain yang masih terkait hal di atas adalah fenomena powerfullnya DPRD di hadapan Kepala Daerah pada masa berlakunya UU No. 22/1999, itu juga bersumber dari ketidaktepatan dalam operasionalisasi prinsip checks and balances ke dalam rumusan konsep LPJ Kepala Daerah yang harus diberikan kepada DPRD pada tiap akhir tahun anggaran; akhir masa jabatan; dan untuk hal-hal tertentu, yang memiliki implikasi pemberhentian kepala daerah. Sementara itu, tidak ada rumusan konsep yang menyebabkan anggota DPRD dapat diberhentikan oleh kepala daerah. Akibatnya, posisi Kepala Daerah menjadi tergantung kepada DPRD dan mengesankan kedudukan kepala daerah itu tidak sejajar dan/atau dibawah DPRD. Fenomena pemecatan Walikota Surabaya, Bambang DH oleh DPRD pada beberapa tahun lalu adalah contoh dari tafsir konsep LPJ kepala daerah kepada DPRD.

Lebih jauh, konsep LPJ Kepala Daerah kepada DPRD dalam prakteknya menimbulkan kolusi dan/atau money politics antara Kepala Daerah dengan DPRD. Tiap akhir tahun anggaran banyak kepala daerah yang menyediakan sejumlah dana khusus 
untuk menyuap anggota DPRD agar LPJnya diterima. Hal ini terpaksa dilakukan oleh kepala daerah karena memang tidak ada parameter yang jelas yang dapat dijadikan pegangan bagi kepala daerah maupun publik dalam penilaian LPJ untuk diterima atau ditolak. Parameternya sangat bersifat politis. Subyektifitas penilaian DPRD demikian menonjol. Disamping itu, tidak ada mekanisme bagi kepala daerah untuk menggugat penilaian DPRD yang dianggapnya tidak obyektif dan berdasar.

Di bawah UU No. 32/2004 problem konsep LPJ Kepala Daerah kepada DPRD bersama dengan problem konsep Pilkada oleh DPRD diatasi (baca: dihilangkan). Kedua konsep tersebut diganti dengan konsep pemberian laporan keterangan pertanggungjawaban kepala daerah kepada DPRD yang tidak berimplikasi pemberhentian kepala daerah dan konsep pilkada langsung. Walaupun dalam praktiknya, terkait pilkada langsung masih timbul masalah ketika DPRD tidak mau mengusulkan pasangan calon kepala daerah-wakil kepala daerah kepada Menteri Dalam Negeri untuk ditetapkan dan disahkan sebagai kepala daerah dan wakil kepala daerah.

Dalam pembuatan Peraturan Daerah di Kabupaten Sumbawa Barat, ternyata dijumpai adanya Perda inisiatif dari legilatif seperti dalam Perda berikut:

a. Nomor 17 Tahun 2007 (Lembaran Daerah KABUPATEN SUMBAWA BARAT Tahun 2007 Nomor 17) dengan Penjelasannya yang dimuat dalam Tambahan Lembaran Daerah 61;

b. Nomor 30 Tahun 2007 tentang PENGELOLAAN HUTAN KEMASYARAKATAN BERBASIS PEMBERDAYAAN DAN LINGKUNGAN (Lembaran Daerah KABUPATEN SUMBAWA BARAT Tahun 2007 Nomor 30) dengan Penjelasannya yang dimuat dalam Tambahan Lembaran Daerah 74;

C. Nomor 2 Tahun 2009, tentang: Alokasi Dana Desa, (Lembaran Daerah KABUPATEN SUMBAWA BARAT Tahun 2009 Nomor 2) dengan Penjelasannya yang dimuat dalam Tambahan Lembaran Daerah 93;

d. Nomor 4 Tahun 2009 tentang Kedudukan Keuangan Kepala Desa dan Perangkat Desa (Lembaran Daerah KABUPATEN SUMBAWA BARAT Tahun 2009 Nomor 3)

\section{Faktor-faktor yang Mempengaruhi Hubungan Kerja DPRD dengan Bupati dalam Melakukan Koordinasi.}


Namun demikian, masalah hubungan Kepala Daerah-DPRD tidak hanya terkait dengan mekanisme rekrutmen dan pertanggungjawaban kepala daerah saja. Akan tetapi, masalah dapat timbul dari pola hubungan kerja sama lain antara Kepala Daerah dengan DPRD yang secara umum meliputi:

a. Perumusan kebijakan umum Pemerintahan Daerah

b. Bidang keuangan daerah

c. Bidang kepegawaian daerah

d. Pengawasan terhadap jalannya pemerintahan daerah

Umumnya, empat pola hubungan kerja sama di atas dapat menimbulkan ketegangan atau konflik antara kepala daerah dengan DPRD pada tataran perumusan dan penetapan instrumen kebijakan berupa peraturan daerah; APBD; keputusan kepala daerah dan/atau peraturan kepala daerah. Inilah potensi masalah dalam hubungan kepala daerahDPRD.

Dalam perumusan dan penetapan Perda dimungkinkan timbul masalah apabila rancangan Perda yang diajukan Kepala Daerah tidak dibahas atau ditangguhkan pembahasannya untuk jangka waktu yang tidak tertentu, atau sebaliknya Kepala Daerah tidak mau menetapkan Perda yang telah mendapat persetujuan DPRD sehingga perda tersebut tidak dapat diberlakukan. Begitu juga menyangkut rancangan perda terkait dengan penyusunan kelembagaan daerah dan kepegawaian daerah.

Masalah juga dapat timbul dalam penetapan APBD tatkala DPRD tidak mau menyetujui RAPBD yang diajukan Kepala Daerah. Permasalahan semacam ini secara empirik pernah terjadi di Sampang, dimana pemerintah daerah selama tiga tahun berturutturut terpaksa menggunakan APBD tahun sebelumnya. Padahal, mengingat kebutuhan dan memperhatikan tingkat inflasi dan harga-harga APBD yang terpaksa dipakai tidak dapat mengakomodasi kebutuhan pembangunan di Sampang. Hal serupa juga pernah terjadi di Propinsi Lampung ketika DPRD Lampung tidak mau membahas RAPBD yang diajukan Gubernur Syachroedin.

Terkait dengan pengawasan jalannya pemerintahan daerah, masalah dapat timbul misalnya dalam hal DPRD menganggap adanya keputusan-keputusan dan/atau peraturan-peraturan kepala daerah yang bertentangan dengan Perda. Bagaimana mencegahnya dan bagaimana membatalkannya mengingat tidak adanya parameter yang jelas mana saja kebijakan publik yang boleh diatur dengan keputusan-keputusan dan/atau peraturan-peraturan kepala daerah. 
Uraian contoh-contoh di atas betul-betul menjadi masalah jika mengingat sistem yang ada tidak dapat menyediakan mekanisme yang memadai untuk meredakan ketegangan dan konflik antara kepala daerah-DPRD. Di negara-negara yang sistem demokrasinya sudah mapan, perbedaan antar lembaga negara dilembagakan dalam kerangka hukum sehingga tidak menjadi sumber ketegangan/konflik. Di Amerika Serikat misalnya, sistem konstitusinya mengenal judicial review untuk memfasilitasi peredaan ketegangan antara eksekutif dan legislatif. Sedangkan di Indonesia, kendatipun judicial review diakui namun pelaksanaannya sangat prosedural dan dikekang oleh sistem yang mengaturnya. Jika suatu peraturan perundang-undangan bertentangan dengan aturan yang lebih tinggi, uji materiil terhadap peraturan perundang-undangan yang lebih tinggi tersebut harus dimulai dari pengadilan negeri bersama-sama dengan pokok perkara yang diadili.

Oleh karena ternyata persoalan utama dari ketegangan dan konflik dalam hubungan kepala daerah-DPRD terletak pada gagalnya sistem yang ada menyediakan mekanisme yang menjadi acuan bersama dalam menyelesaikannya, maka solusinya adalah gagasan sistemik dalam kerangka hukum sebagaimana lazim diterapkan di negaranegara yang sudah mapan demokrasinya. Gagasan sistemik tersebut bila dikaitkan dengan uraian problematika hubungan kepala daerah-DPRD di atas, mewujud dalam upaya menyediakan mekanisme hukum untuk mengatasi konflik dalam hal proses legislasi; proses penganggaran; dan pengawasan.

Dalam hal proses legislasi perlu ditetapkan mekanisme peradilan yang efisien yang menjamin tiap pihak baik Kepala Daerah maupun DPRD dapat mengggugat pihak yang menghambat proses legislasi daerah sekaligus mendapatkan solusi yang adil demi produk legislasi berkualitas. Begitu juga menyangkut konflik dalam bidang pengawasan. Sementara untuk konflik proses penganggaran, apabila DPRD tidak mau membahas rancangan APBD perlu adanya mekanisme yang diatur dalam peraturan perundangundangan yang memungkin kepala daerah dapat membentuk tim adhoc independen yang beranggotakan kalangan profesional dan akademisi untuk membahas RAPBD menggantikan peran DPRD. Prinsipnya, semua gagasan mekanisme solutif di atas harus diatur dalam kerangka hukum. Inilah operasionalisasi konsep yang tepat dari prinsip negara hukum menyangkut hubungan kepala daerah-DPRD.

\section{PENUTUP}

\section{Simpulan}


a. Bahwa hubungan fungsi dan tata kerja antara DPRD dengan Kepala Daerah baik dalam Undang-undang Nomor 22 Tahun 1999 maupun Undang-undang Republik Indonesia Nomor 32 Tahun 2004 tentang Pemerintahan Daerah adalah sama yaitu meliputi hubungan legislasi, pemilihan, anggaran, pertanggungjawaban, pengawasan, administrasi, inisiatif, dan aspirasi rakyat. Namun dalam Undangundang Republik Indonesia Nomor 32 Tahun 2004 tentang pemerintahan daerah, memberikan peluang dalam pelaksanaan pemerintahan daerah dalam "good governance" pada Negara Kesatuan Republik Indonesia Tahun 1945 dan Pancasila.

b. Hubungan fungsi dan tata kerja DPRD dengan Kepala Daerahndalam pelaksanaannya sangat dipengaruhi faktor yuridis dan faktor non yuridis, dimana dalam undang-undang pemerintahan daerah sekarang secara tegas mengatur hubungan organ sistem pemerintahan yang baru lebih memperjelas dan mempertegas hubungan hirarki antara kabupaten/kota dengan provinsi, walaupun tidak munafikkan orang-orang di DPRD merupakan jebolan politisi yang bertanggungjawab kepada hanya partainya daripada rakyatnya yang memberikan wakilnya kepada mereka.

\section{Saran-saran}

a. Hendaknya hubungan fungsi dan tata kerja yang ada selama ini antara DPRD dengan Kepala Daerah tetap dijaga, dibina, dan dikembangkan dengan prinsip saling menghormati, kemitraan, kesetaraan, dan sebagai mitra kerja dalam pemerintahan daerah yang demokratis, karena apabila hal ini untuk kepentingan diri sendiri maupun kepentingan politisnya, maka besar kemungkinan akan menjadikan kolaborasi baru untuk melakukan korupsi secara pada penentuan anggaran dan pengesahan peraturan daerah yang tidak berpihak pada kepentingan masyarakat.

b. Dengan melihat peluang-peluang kolaborasi bersama antara DPRD dan Pemerintah Daerah pada Undang-undang Nomor 32 Tahun 2004 dengan prinsip check and balances, maka masyarakat harus mengisi ruang partisipasi publik yang diatur peraturan daerah, agar masyarakat menjadi sebagai alat kontrol sosial yang efektif. 


\section{Daftar Pustaka}

Anom Surya Putra, 2003 . Hukum Konsitusi Masa Transisi . Bandung : Nuasa Cengdekia . Azhary, 1995, NegaraHukum Indonesia, Analisis Yuridis Normatif, tentang Unsur Unsurnya,Jakarta : UI Press;

Bagir Manan, 1995, Hubungan antara Pusat dan Daerah Menurut UUD 1945, Jakarta : Dinar Harapan;

Bambang Sunggono, 2002, Metodologi Penelitian Hukum, Jakarta : Raja Grafindo Persada; Bernard Arief Sidharta, 2000. Refleksi tentang struktur Ilmu Hukum.

Fakhurohman dKK.2004. Memahami Keberadaan Mahkamah Konstistusi Di Indonesia. Bandung. Citra Adityia Bakti.

Josef Riwu Kawo, 2001, Prospek Otonomi Daerah di Negara Republik Indonesia, Jakarta :

Raja Grapindo Persada;

Kewenangan Antara DPRD dan Kepala Daerah, Bandung : Alumni;

Kansil, C. S. T. 1979, Pokok - Pokok Pemerintahan di Daerah, Jakarta : Aksara Baru;

Krisna Harahap, 2004. Konstitusi Republik Indonesia, Sejak Proklamasi hingga Reformasi. Bandung; Grafitri Budi Utomo;

La Ode .Husen 2004. Negara Hukum, Demokrasi dan Pemisahan Kekuasaan. Makassar. Laboratorium Hukum Fakultas Hukum - UMI;

Mansyur Muhammad Tolchan, 1970, Pembahasan Beberapa Aspek tentang Kekuasaan Eksekutif dan Legislatif Negara Indonesia, Yogyakarta : Radya Indria;

Marbun, B. N, 2005, DPRD dan Otonomi Daerah Setelah Amandemen Undang-Undang Dasar 1945 dan Undang-Undang Otonomi Daerah 2004, Jakarta : Pustaka Sinar Harapan;

Morissan, 2005, Hukum Tata Negara Republik Indonesia Era Reformasi, Jakarta : Ramdina Prakarsa;

Ni' matul Huda, 2004, Politik Ketatanegaraan Indonesia ( Kajian Terhadap Dinamika Perubahan UUD 1945 ), Jakarta FH UII Press.

Peraturan Pemerintah No. 39 Tahun 2001 Tentang Penyelenggaraan Dekonsentrasi, Jakarta; 
Peraturan Pemerintah No. 52 Tahun 2001 Tentang Penyelenggaraan Tugas Pembantuan, Jakarta;

Peraturan Pemerintah No. 106 Tahun 2000 Tentang Pengelolaan dan Pertanggungjawaban dalam Melaksanakan Dekonsentrasi dan Tugas Pembantuan, Jakarta

Ridwan Syahrani, H. 1999, Rangkuman Intisari Ilmu Hukum, Bandung : Citra Aditya Bakti;

Rozali Abdullah, 2005. Pelaksanaan Otonomi Luas dengan Pemilihan Kepala Daerah Secara Langsung. Jakarta. Raja Grapindo Persada.

Satjipto Rahardjo, 2000, Ilmu Hukum, Bandung : Citra Aditya Bakti;

Tjahya Supriatna, 1993, Sistem Administrasi Pemerintahan di Indonesia, Jakarta : Bumi Aksara;

Undang - Undang Republik Indonesia No. 5 Tahun 1974 Tentang Pokok - Pokok Pemerintahan Daerah, Jakarta

Widjaja, A, W, H., 1998, Percontohan Otonomi Daerah di Indonesia, Jakarta : Rineka Cipta; 2003, Otonomi Desa Merupakan Otonomi Yang Asli, Bulat dan Utuh, Jakarta :Raja Grafindo Persada; Undng - Undang Dasar 1945 dengan Perubahannya 1999 - 2002; 